Hemisphere, Second International Symposium Winnipeg, Manitoba, February 1997. General Technical Report NC-190. United States Department of Agriculture, Forest Service, North Central Forest Experiment Station, St. Paul, Minnesota, pp. 487-497.

24. WELLICOME, T.I. and E.A. HAUG.
1995. Updated Report on the Status of the Burrowing Owl in Canada. Committee on the Status of Endangered Wildlife in Canada, Ottawa, Ontario.

25. ZAR, J.H. 1996. Biostatistical Analysis. $3^{\text {rd }}$ Edition. Prentice-Hall, Inc., Upper Saddle River, New Jersey.

\title{
ADDITIONAL NOTES ON THE DOVEKIE SPECIMEN FROM MANITOBA
}

SPENCER G. SEALY, Department of Zoology, University of Manitoba, Winnipeg, MB R3T 2N2, and HARRY R. CARTER, Department of Wildlife, Humboldt State University, Arcata, CA 95521, U.S.A.

\section{Introduction}

The Dovekie (Alle alle), or Little Auk, is a high-arctic species that breeds in large numbers on Greenland, Svalbard (Spitzbergen), Franz Josef Land and Novaya Zemlya, with small numbers nesting on Iceland and Baffin Island. ${ }^{20}$ Some nesting colonies, particularly in northwestern Greenland, are comprised of millions of individuals. ${ }^{20}$ Small numbers of Dovekies also occur in the Bering Sea and adjacent waters and breeding is suspected at several sites. ${ }^{5}$ Although nothing is known of the seasonal movements of Dovekies in the Bering Sea, in the Atlantic Ocean, Dovekies winter offshore in low-arctic waters from Newfoundland to northern Norway and occur regularly off Nova Scotia and in the Gulf of Maine, northern Scotland and the North Sea. ${ }^{20}$, ${ }^{31}$ From time to time, driven by food shortages caused in some years by severe storms, thousands of Dovekies move south of the normal winter range, in the western Atlantic Ocean, as far as Cuba and Madeira. ${ }^{13}$ During some of these movements many individuals are blown on to shore, resulting in "wrecks" of dead and weakened birds inland and along the Atlantic coast of North America.7, 10, 18, 27. 28, 29, 34

Seventeen Dovekies are known to have reached inland as far as the Great Lakes and surrounding region of North America. 6, 12, 23, ${ }^{24}$ One of these was collected north and west of the Great Lakes, along the eastern shore of Lake Winnipeg, in central Manitoba. ${ }^{1,11,16,22}$ Additional details pertaining to this specimen are presented in this paper and the circumstances surrounding the occurrence of a Dovekie in Manitoba are examined.

\section{The Dovekie}

A Dovekie swimming weakly near the shore of Lake Winnipeg at Warren Landing $\left(53^{\circ} 41^{\prime} \mathrm{N}, 97^{\circ} 52^{\prime} \mathrm{W}\right), 37 \mathrm{~km}$ southwest of Norway House, was collected by Constable James MacDonald on 7 November 1944. The specimen was sent to Gerald W. Malahar, acting supervisor of the Manitoba Department of Natural Resources, who forwarded it to Lawrence T.S. Norris-Elye, curator at the former Manitoba Provincial Museum. ${ }^{16,22}$ The dried, unsexed specimen 
was eventually deposited in the collection of the (now) Manitoba Museum (number 2303, original number 1219). The bird had been partially eaten by insects or another scavenger; the sternum and ribs on the left side, the left scapula and some vertebrae were exposed, but the plumage was otherwise in good condition (Fig. 1). The white throat sullied with sooty brown and the browner and slightly worn flight feathers (primaries, secondaries and wing coverts) revealed that the bird was in its first winter (Basic I) plumage. By contrast, older birds have evenaged, black feathers on the back and wings. ${ }^{4}$ The white spots above the eyes, typical of Dovekies of all ages, were perceptible only as a tiny speck of white feathers above the right eye, as the eyelids of both eyes were shriveled and sunken. Descriptions and illustrations of plumages of nearly fledged nestlings and first-winter birds state or suggest that these spots are smaller than those of older birds. ${ }^{4,10,21}$

This is the only record of the Dovekie for Manitoba. This specimen and two collected in Minnesota ${ }^{12}$ and two from Wisconsin ${ }^{24}$ are the westernmost inland records of the Dovekie in North America, although these localities and those of some of the other specimens taken in the eastern Great Lakes are almost equidistant from the nearest

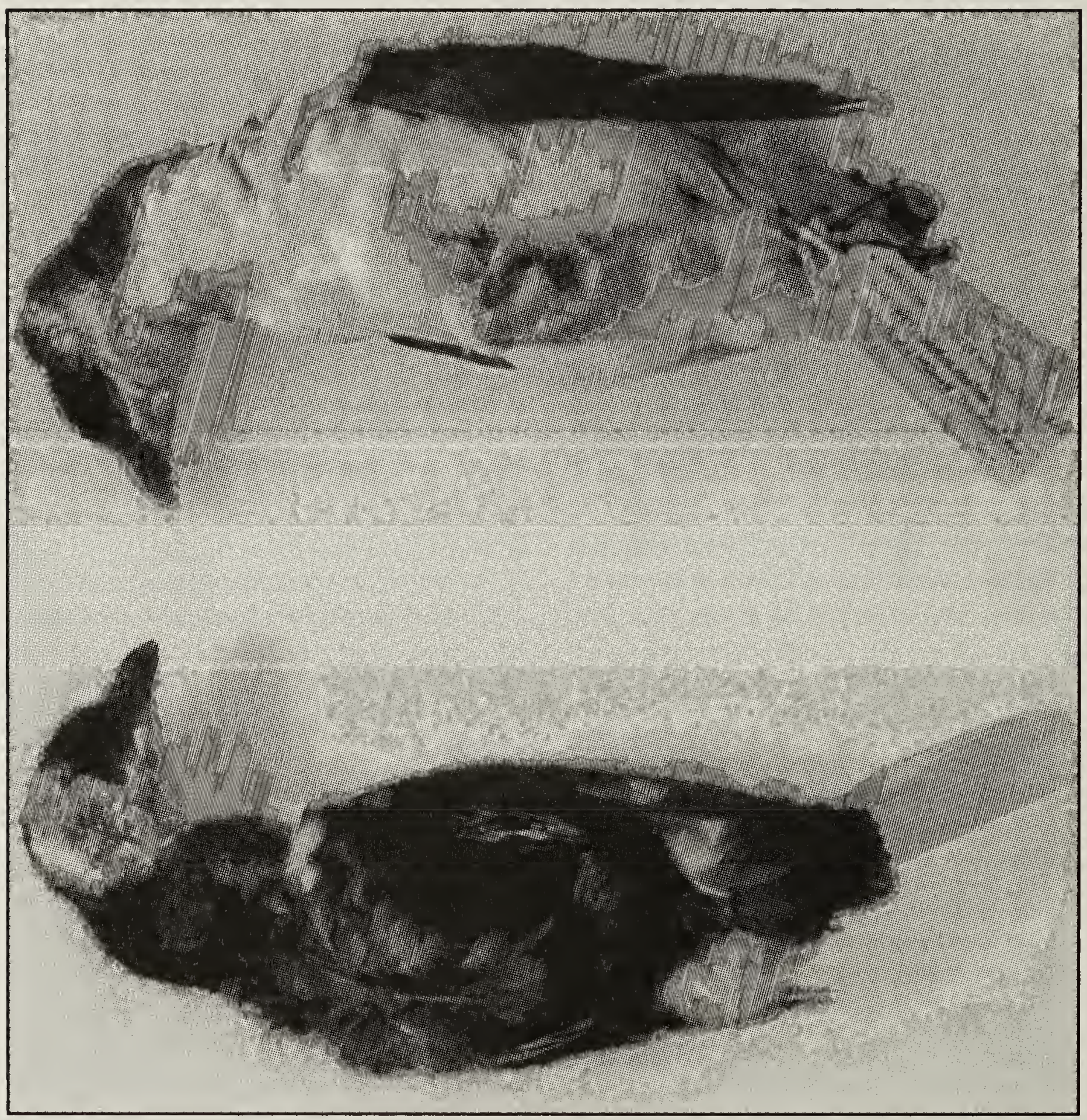

Figure 1. Dovekie (MM 2303) collected on 7 November 1944 near the shore of Lake Winnipeg, Warren Landing, Manitoba. Upper photograph, ventral view; lower, dorsal view. 
marine waters, Hudson Bay and the Atlantic Ocean, respectively. But as discussed later, distance to the nearest marine habitat may be inconsequential when the origins of vagrants are considered. One record from South Dakota more than 100 years ago cannot be confirmed. ${ }^{33}$ Dovekies have not been recorded off Churchill, in Hudson Bay, but offshore seabird surveys have not been conducted there. Other auks, however, such as Thick-billed Murres (Uria lomvia) and Common Murres ( $U$. aalge), and, more frequently, Black Guillemots (Cepphus grylle), have been recorded in Hudson Bay. ${ }^{15}$ Single specimens of the Black Guillemot have been collected inland near Churchill and in southern Manitoba ${ }^{19}$ and Ancient Murrelets (Synthliboramphus antiquus), inhabitants of the Pacific Ocean, have also been taken, one in Winnipeg and one on the southern basin of Lake Winnipeg. ${ }^{26}$

\section{Origin}

We assume that this is a genuine vagrant and not an escapee or an individual whose passage was assisted in any way by humans. Rationale for this assumption has been presented for other auks found far out of range. ${ }^{17}$ As well, a Dovekie so far inland in North America is not without precedence. Spanning the years 1881 to 1998 , at least 16 other individuals have been recorded, many also in November, on and beyond the Great Lakes (Carter and Sealy, unpublished review).

Two subspecies of the Dovekie are recognized on the basis of size. During the breeding season the nominate subspecies alle occurs on Baffin Island, Greenland, Iceland, and $\mathrm{S}$ valbard ${ }^{20}$, whereas the larger polaris occurs only in the western Russian Arctic, at Franz Josef Land and Novaya Zemlya. ${ }^{8}$. ${ }^{30}$ Although measurements of individuals from these populations overlap ${ }^{5,30}$, a recent multivariate analysis of external measurements of a large sample of Dovekies, consisting of museum specimens and individuals breeding on Svalbard and Franz Josef Land, confirmed the morphological distinctness of the populations, with alle averaging smaller than polaris in all dimensions. ${ }^{30}$ The Dovekie from Manitoba is referable to alle as its measurements (flattened wing, $114.5 \mathrm{~mm}$; exposed culmen, $13.2 \mathrm{~mm}$; tarsus diagonal, $20.9 \mathrm{~mm}$ ) are at the lower end of the range for this subspecies. ${ }^{5,30,32}$

The Manitoba specimen most likely originated from populations in the Atlantic Ocean, which number in the tens of millions, but the possibility remains that this bird originated from the small Bering Sea population. The Dovekie specimens from the Bering Sea have been referred to alle but overlap in measurements between populations of the two subspecies made subspecific identification problematic. The Pacific population numbers only in the hundreds, despite the fact that its presence has been recognized only since the 1960s. ${ }^{5}$, ${ }^{10}$ Nevertheless, vagrants of other species of auks, some also with small breeding populations distributed in the north Pacific Ocean, have been recorded in the interior across North America, the Atlantic Ocean and in Europe. ${ }^{14,17,} 25,26$

\section{Vagrancy and route of travel}

Gale-force southeasterly winds in the late fall and winter have been linked with some of the large wrecks of Dovekies in eastern North America. 4, 7, 9, 10 Dovekies apparently withstand most storms at sea, but evidence suggests that in some years prolonged gales drive their primary food, planktonic crustaceans $^{2}$, to depths greater than Dovekies can reach. Weakened by such storm-induced food shortages or perhaps forced to make longer flights in search of food, Dovekies are prone to being blown inshore and inland. 4.7.9. ${ }^{10,31}$ Complicating the picture, however, is the finding that not all large incursions have been linked exclusively with the conditions brought about by severe storms. ${ }^{34}$

The available information suggests that the Dovekie recorded in Manitoba in early November 1944 was one such unexplained 
occurrence. The weather in east-central Manitoba during five days prior to discovery of the bird was not characterized by unseasonably strong winds or precipitation (Environment Canada, Atmospheric Environment Service). Similarly, no direct link to severe weather conditions at the time and place of inland recovery was associated with a Dovekie shot in late October 1993 near Ottawa, Ontario. ${ }^{6}$ None of the other records of Dovekies recorded on or in the vicinity of the Great Lakes was from 1944 nor were any Dovekies reported during the years of the most celebrated wrecks on the Atlantic coast of North America, in November 1891 and November and December 1932. ${ }^{18}$ As well, none was recorded during the years that the other 12 smaller flights or wrecks occurred on the eastern seaboard since the mid-1800s. ${ }^{7,9}$

Many interesting questions remain. First, was the Dovekie blown off course during migration or did it make a navigational error and end up in the interior of Manitoba instead of the waters off northern Newfoundland? Most migratory movements of Dovekies from the massive colonies in northwestern Greenland to the Labrador Sea and eastern Newfoundland waters continue through November and into December (W.A. Montevecchi, pers. comm.). Dovekies from other populations in the eastern Atlantic Ocean, however, winter off southwestern and southeastern Greenland, with birds banded on Svalbard and recovered off southwestern Greenland between November and January. ${ }^{3,31}$

Second, did the Dovekie fly, possibly assisted by wind, westward along the Gulf of St. Lawrence, through the Great Lakes, to Lake Winnipeg, or did it arrive directly from the high arctic, possibly via Hudson Bay, or overland from the Bering Sea or adjacent waters? A synthesis of the other Dovekie records around the Great Lakes in relation to weather records and the major and minor wrecks over the past 150 years may help shed light on this subject.

\section{Acknowledgements}

Janis Klapecki loaned the Dovekie specimen under her care in The Manitoba Museum and provided other information pertaining to the specimen. Rob Barrow, also of the The Manitoba Museum, prepared the photographs. Robert H. Day and Peter Pyle shared their knowledge of plumages of the Dovekie and other seabirds and Nina J. Karnovsky provided information on populations and movements of Dovekies. William A. Montevecchi, Iain J. Stenhouse and an anonymous reviewer commented on drafts of the manuscript. Montevecchi also pointed out an important reference. Our work on vagrancy in seabirds is supported by grants from the Natural Sciences and Engineering Research Council of Canada.

\section{AMERICAN ORNITHOLOGISTS'}

UNION. 1998. Check-list of North American Birds, 7th Edition. American Ornithologists' Union, Washington, D.C.

2. BRADSTREET, M.S.W., and R.G.B. BROWN. 1985. Feeding ecology of the Atlantic AIcidae. In: D.N. Nettleship and T.R. Birkhead (eds.). The Atlantic Alcidae. Academic Press, London. Pp. 263-318.

3. BROWN, R.G.B. 1985. The Atlantic Alcidae at sea. In: D.N. Nettleship and T.R. Birkhead (eds.). The Atlantic Alcidae. Academic Press, London. Pp. 383-426.

4. CRAMP, S. (ed.). 1985. Handbook of the Birds of Europe and the Middle East and North Africa: The Birds of the Western Palearctic. Volume IV. Oxford University Press, Oxford.

5. DAY, R.H., A.R. DEGANGE, G.J. DIVOKY and D.M. TROY. 1988. Distribution and subspecies of the Dovekie in Alaska. Condor 90:712-714.

6. DI LABIO, B.M. 1995. Another Dovekie record from eastern Ontario. Ontario Birds 13:31-34.

7. FISHER, J., and R.M. LOCKLEY. 1954. Sea-Birds. Collins, London.

8. FLINT, V.E., and A.N. GOLOVKIN. 1990. Birds of the USSR: Auks (Alcidae). Nauka, Moscow. 
9. GASTON, A. J. 1988. The mystery of the murres: Thick-billed Murres, Uria lomvia, in the Great Lakes region, 1890-1986. Canadian Field-Naturalist 102:705-711.

10. GASTON, A.J. and I.L. JONES. 1998. The Auks. Oxford University Press, New York.

11. GODFREY, W. E. 1986. The Birds of Canada, revised edition. National Museums of Canada, Ottawa.

12. GREEN, J.C., and R.B. JANSSEN. 1975. Minnesota Birds. University of Minnesota Press, Minneapolis.

13. HARRISON, P. 1983. Seabirds, An Identification Guide. Houghton Mifflin, Boston.

14. HØRRING, R. 1933. Aethia cristatella (Pallas) skudt ved lsland. [Crested Auklet shot in Iceland]. Dansk ornithologisk Forenings Tidsskrift 27:103-105.

15. JEHL, J.R., Jr., and B.A. SMITH. 1970. Birds of the Churchill region, Manitoba. Manitoba Museum of Man and Nature, Special Publication Number 1.

16. [LAWRENCE, A.G.]. 1945. New addition to the Manitoba bird list. Chickadee Notes, no. 1,254. Winnipeg Free Press, April 13, 1945.

17. MAUMARY, L., and P. KNAUS. 2000. Marbled Murrelet in Switzerland: a Pacific Ocean auk new to the Western Palearctic. British Birds 93:190-199.

18. MURPHY, R.C. and W. VOGT. 1933. The Dovekie influx of 1932. Auk 50:325-349.

19. NERO, R.W. 1992. Second winter record of Black Guillemot at Churchill, Manitoba. Blue Jay 50:113-114.

20. NETTLESHIP, D.N. and P.G.H. EVANS. 1985. Distribution and status of the Atlantic Alcidae. In: D.N. Nettleship and T.R. Birkhead (eds.). The Atlantic Alcidae, Academic Press, London. Pp. 53-154.

21. NORDERHAUG, M. 1980. Breeding biology of the Little Auk (Plautus alle) in Svalbard. Norsk Polarinstitutt Skrifter Number 173:1-45.
22. NORRIS-ELYE, L.T.S. 1945. Additions to the bird list of Manitoba. Canadian FieldNaturalist 59:173.

23. PAYNE, R.B. 1983. A distributional checklist of the birds of Michigan. Miscellaneous Publications, Museum of Zoology, University of Michigan, Number 164.

24. ROBBINS, S.D., Jr. 1991. Wisconsin Birdlife. University of Wisconsin Press, Madison.

25. SEALY, S. G., H. R. CARTER, W. D. SHUFORD, K. D. POWERS, and C. A. CHASE III. 1991. Long-distance vagrancy of the Asiatic Marbled Murrelet in North America, 1979-1989. Western Birds 22:145-155.

26. SEALY, S.G., H.R. CARTER, and J. HUDON. 2001. Specimen records and sightings of Ancient Murrelets from the Canadian prairie provinces. Blue Jay 59:175-182.

27. SERGEANT, D.E. 1952. Little Auks in Britain, 1948 to1951. British Birds 45:122133.

28. SNYDER, D.E. 1960. Dovekie flights and wrecks. Massachusetts Audubon: January/ February, pp. 117-121.

29. SPRUNT, A. Jr. 1938. The southern Dovekie flight of 1936. Auk 55:85-88.

30. STEMPNIEWICZ, L., M. SKAKUJ, and L. ILISZKO. 1996. The Little Auk Alle alle polaris of Franz Josef Land: a comparison with Svalbard Alle a. alle populations. Polar Research 15:1-10.

31. STENHOUSE, 1.J., and W.A. MONTEVCCHI. 1996. Winter distribution and wrecks of Little Auks (Dovekies) Alle a. alle in the northwest Atlantic. Sula 10:219-228.

32. STENHOUSE, J.H. 1930. The Little Auk (Alle alle polaris Sub-Sp. nov.) of Franz Josef Land. Scottish Naturalist 47:47-49.

33. VAN SICKLE, S. 1988. A Dovekie in South Dakota? South Dakota Bird Notes 40:95-96.

34. VEIT, R.R., and W.R. PETERSEN. 1993. The Birds of Massachusetts. Massachusetts Audubon Society, Lincoln, MA. 